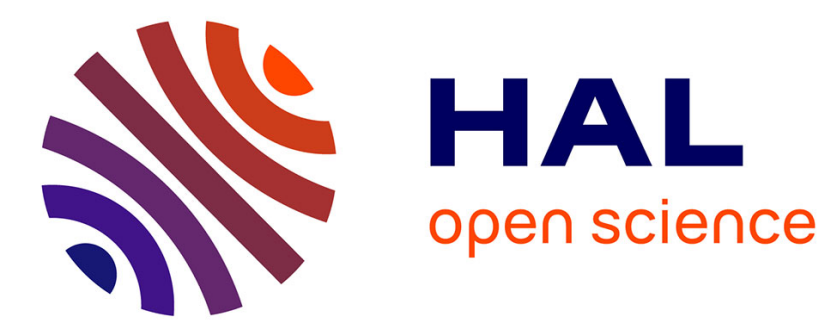

\title{
Ineffective Obsessions in Brazilian Academia and Proposals Towards Meritocracy
}

Miguel Abambres, Tiago Ribeiro, Ana E Sousa, Eva Lantsoght

\section{To cite this version:}

Miguel Abambres, Tiago Ribeiro, Ana E Sousa, Eva Lantsoght. Ineffective Obsessions in Brazilian Academia and Proposals Towards Meritocracy. 2018. hal-02074849v2

\section{HAL Id: hal-02074849 \\ https://hal.science/hal-02074849v2}

Preprint submitted on 14 Nov 2019

HAL is a multi-disciplinary open access archive for the deposit and dissemination of scientific research documents, whether they are published or not. The documents may come from teaching and research institutions in France or abroad, or from public or private research centers.
L'archive ouverte pluridisciplinaire HAL, est destinée au dépôt et à la diffusion de documents scientifiques de niveau recherche, publiés ou non, émanant des établissements d'enseignement et de recherche français ou étrangers, des laboratoires publics ou privés.

\section{(c)(1)}

Distributed under a Creative Commons Attribution| 4.0 International License 
Abambres M, Ribeiro T, Sousa A, Lantsoght E (2018). Ineffective Obsessions in Brazilian Academia

and Proposals Towards Meritocracy, hal-02074849

(C) 2018 by Abambres M et al. (CC BY 4.0)

\title{
Ineffective Obsessions in Brazilian Academia and Proposals Towards Meritocracy
}

\author{
Miguel Abambres ${ }^{1}$, Tiago Ribeiro ${ }^{2}$, Ana Sousa ${ }^{2}$ and Eva Lantsoght ${ }^{3,4}$ \\ 1 R\&D, Abambres' Lab, 1600-275 Lisbon, Portugal; abambres@netcabo.pt \\ 2 Independent Researcher, Lisbon, Portugal \\ ${ }^{3}$ Researcher, Department of Engineering Structures, Delft University of Technology, The Netherlands; \\ E.O.L.Lantsoght@tudelft.nl \\ ${ }^{4}$ Professor, Politécnico, Universidad San Francsico de Quito, Quito, Ecuador
}

\begin{abstract}
Albeit its constitutional claim for quality, Brazilian academia has largely been referred to as unmeritocratic and academic hiring is still inward-oriented. Lattes platform, a public curricular information system, reflects elements of this protectionism. This article assesses two 'obsessions' in Brazilian academia: (i) the 'mandatory' Lattes CV, and (ii) the candidates' assessment criteria in public tenders for faculty positions. Several pros and cons (mostly) of the Lattes platform are identified. The following improvements are proposed: (i) evaluations in public tenders based only on candidate's CV, interview, and a sample lecture, (ii) the dismissal of Lattes CV as a mandatory format, and (iii) the use of platforms as Microsoft Academic, Google Scholar, ORCID or ResearcherID for curricular information. With these recommendations, Brazil can move towards a more meritocratic academic hiring system.
\end{abstract}

Keywords: Academia, Brazil, Faculty Position, Lattes CV, Meritocracy, Public Tender.

\section{Introduction}

Meritocracy is a system in which individuals make progress and gain the fruits of their own efforts. It uses pre-established criteria to assess people according to their performance, regardless their seniority and social networking. According to Barbosa [1] and Pinheiro [2], Brazil is a flawed meritocracy, since it (i) does not promote a fair assignment of citizens' own labor efforts, and (ii) endangers the entrepreneurial spirit by imposing bureaucracy and inefficient rules. Back in 1996, Barbosa [1] supported the idea that public tenders (i) employ unsuitable assessors and assessment methods, and/or (ii) allow biased results due to personal relations. In ' $3 \%$ ', a 2016 Brazilian self-descriptive fictional work, merit can only be measured if one formulates the right maze of tests and administers them to every member of society in the same way [3]. This can be associated with what happens in Brazilian public tenders today, since their definition in the Federal Constitution of 1988 [ [4], and the case of academia is not excluded. There are meritocratic systems that select the best candidates by their qualifications and/or former performance records in certain tasks. Since academia is a place of innovation and knowledge production, one of its tasks should be the quest for paradigm changes, especially with respect to the traits desired for its employees [ $\underline{5}$. 
Abambres M, Ribeiro T, Sousa A, Lantsoght E (2018). Ineffective Obsessions in Brazilian Academia and Proposals Towards Meritocracy, hal-02074849

(C) 2018 by Abambres M et al. (CC BY 4.0)

The Brazilian National Council for Scientific and Technological Development (CNPq) launched in 1997 a curricular information system denominated Lattes (CNPq 2018a), in honor to Cesare Lattes, a worldrenowned Brazilian physicist [6]. CNPq's aim was to integrate all curricula of people associated to Brazilian scientific communities into a single database, through the so-called 'Lattes Curriculum' (also named Lattes $\mathrm{CV}$ in this manuscript) - a national 'standard' for most academics []]

This article aims to describe, analyze, and propose alternatives for two critical 'obsessions' taking place in Brazilian academia for a long time: (i) the way candidates are assessed in public tenders for faculty positions, and (ii) the mandatory Lattes CV. In the authors' opinion, these two paradigms are seriously jeopardizing Brazil's development and pluralism in science and higher education - two major pillars of any society.

\section{Current state of hiring processes in Brazil}

\subsection{Public tenders for academic positions}

A study [ [ $]$ that investigated the public tender assessment criteria for faculty positions in 59 Brazilian federal Universities concluded that most employ (i) a written exam, (ii) a sample lecture, and (iii) CV evaluation. Some include an extra assessment called 'Memorial', typically for full professor positions, where a research project is orally proposed. Sample lectures, where a shorter lecture is given for a jury in order to assess the didactic skills of the candidate, are always optional and depend on the decision of the administrative department in charge. The written exams cover 1-3 out of 10-20 topics, being only the latter publicly announced prior to the exam [5]. This evaluation is a standardized test, for which the candidate can study to obtain a good grade. The shortcomings of using a standardized test are described in section 3.1.

The final score of each candidate is the weighted sum of the partial scores in each type of assessment (typically on a 0-10 scale), as described in the bottom of Table 1. Siqueira et al. [్] found five distinct assessment criteria (i.e., weight distribution for all types of assessment), which are presented in Table 1 along with three others found in recent public tender calls. In most cases, the knowledge and CV assessments are the most and less weighted, respectively. In most public tenders in academia there is a qualifying phase, i.e. candidates are first classified, typically based on the written and/or oral exams (sometimes the sample lecture also - e.g. [ [ $]$ ), and only those who score higher than a predetermined minimum proceed to the final stage of the selection procedure.

\subsection{Use of the Lattes CV platform}

'Lattes is like an idol, thus requiring to be fed everyday' [10], perfectly and partially reflects the prevalent environment in Brazilian public universities. 'Perfectly' because Lattes CV has become almost an obsession for important sectors within academia (including private institutions) - e.g., it's a key element in selection processes for research funding or academic positions, and most public tenders for faculty positions recommend or require its use. 'Partially' because there is a reasonable number of full-time professors that 
Abambres M, Ribeiro T, Sousa A, Lantsoght E (2018). Ineffective Obsessions in Brazilian Academia and Proposals Towards Meritocracy, hal-02074849

(C) 2018 by Abambres M et al. (CC BY 4.0)

have a stable career and do not show any interest in upgrading it. Dias et al. [11] published a histogram of the number of Lattes CVs, among 4.156 .635 (one per person) published by April $5^{\text {th }} 2015$, last updated on each date in 1997-2015, as shown in Figure 1. It is shown that roughly $60 \%$ and $40 \%$ of the curricula were not updated during the last 1.25 and 2.25 years, respectively, which reveals that either (i) the scientific productivity of those professionals is low, and/or (ii) Lattes CV is not effective enough to be the first choice for the vast majority of those users.

Table 1. Weight distribution for distinct public tender assessment criteria.

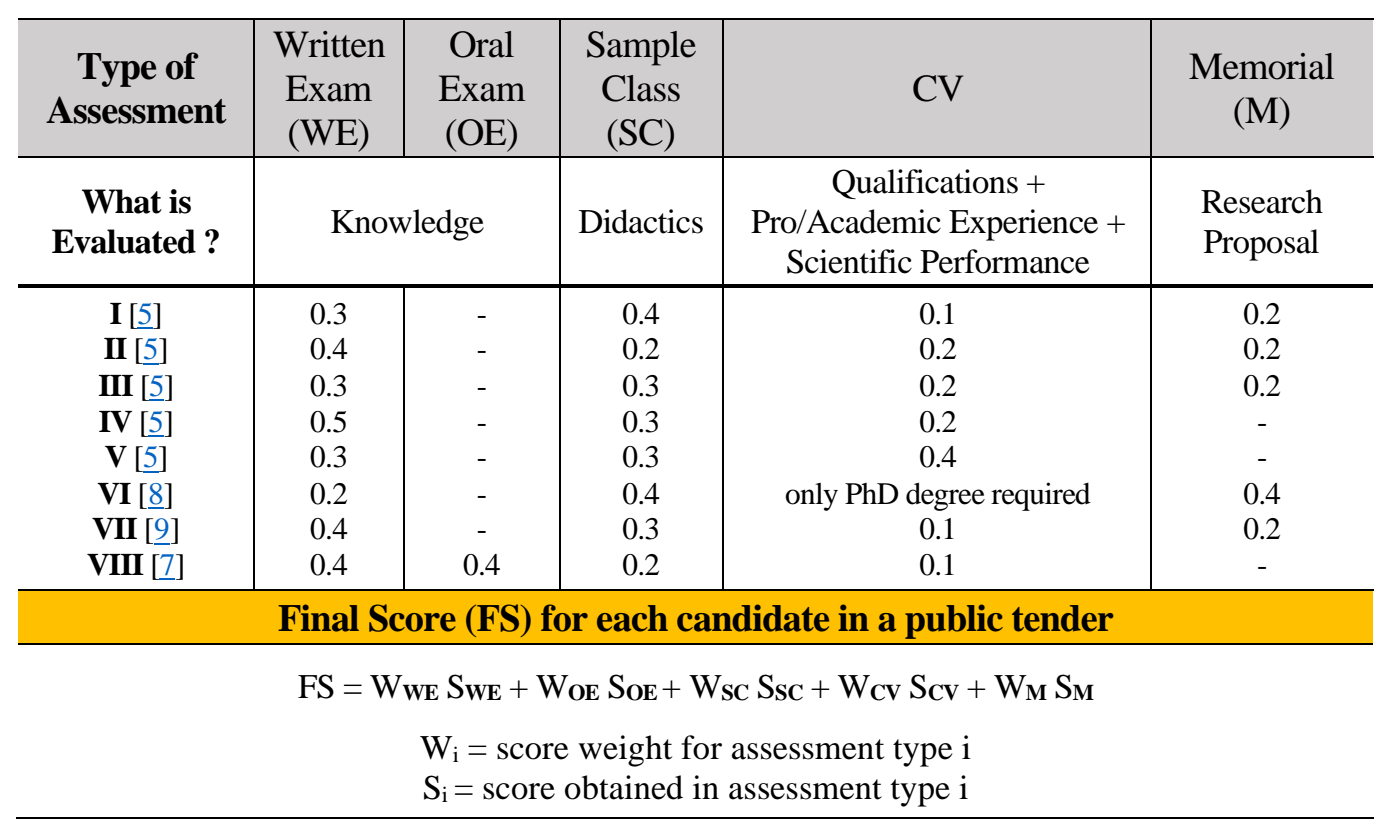

\section{Analysis of current procedures}

\section{1. 'Brazilian' public tenders for faculty positions}

According to Fontainha [12], the individual success or failure in public tenders depends on attendees' capacity to adapt to the type of assessment employed. For the case of the hiring procedures in Brazil, the success of a candidate depends on how well he/she performs on (written and oral) standardized tests. Fontainha et al. [1] $]$ showed that public tenders are used to select people who are neither (i) the most experienced nor (ii) the most qualified. Indeed, this reality is not surprising when one realizes the dimension of the editorial and digital markets involved in the preparation of public tender candidates, as described next. Besides, Downie [14] noted that the fact that the exams are in Portuguese is also a major barrier to hiring international faculty. 
Abambres M, Ribeiro T, Sousa A, Lantsoght E (2018). Ineffective Obsessions in Brazilian Academia and Proposals Towards Meritocracy, hal-02074849

(C) 2018 by Abambres M et al. (CC BY 4.0)

\section{\# updated CVs}

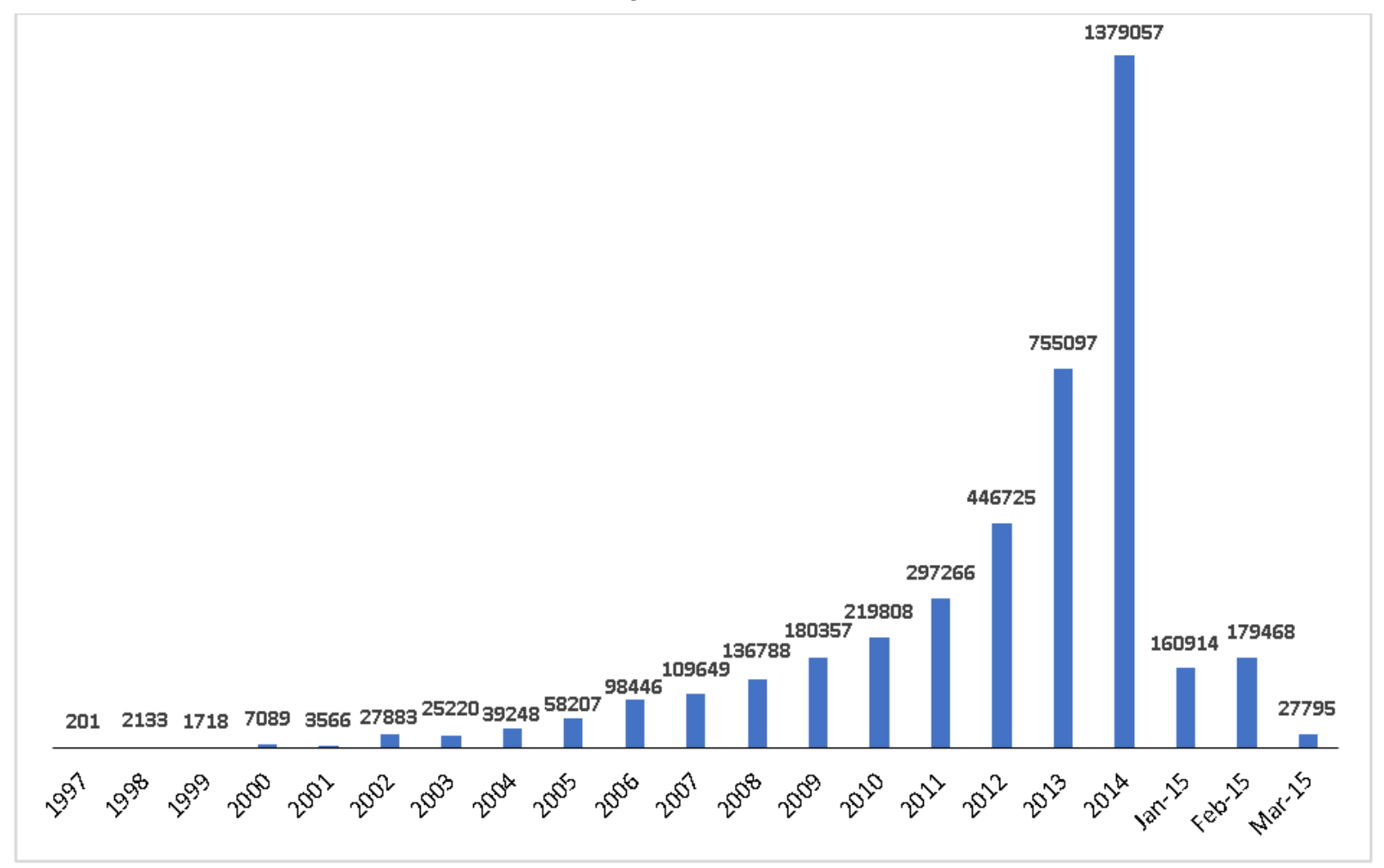

Figure 1. Number of Lattes CVs among 4.156 .635 (published by 5/4/2015), last updated on each indicated date.

Many public tender-oriented markets in Brazil have shown an increasing growth in the last years. De Araújo [4] highlights the following editorial references, among many available: (i) 'How to pass exams and

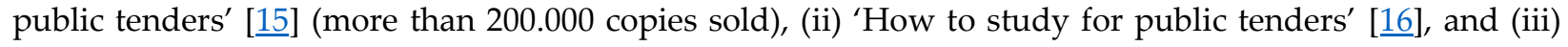
'Manual for public tender attendees: the path of common people' [17]. On the social media side, there is an interactive online platform [18] to help in the preparation of public tenders, gathering more than 100.000 members. The major digital market consists of YouTube videos and channels - Figures 2-3 illustrate the registered 'popularity' on August 12 2018 ('concurso público Brasil' is Portuguese for 'public tender Brazil', and 'como passar em concurso público' is Portuguese for 'how to be approved in a public tender'). Figure 2 shows that five videos on the topic have more than 1 million views, and Figure 3 shows that out of 33 channels dedicated to the topic of passing public tenders, two have more than 700.000 subscribers. 
Abambres M, Ribeiro T, Sousa A, Lantsoght E (2018). Ineffective Obsessions in Brazilian Academia and Proposals Towards Meritocracy, hal-02074849

(C) 2018 by Abambres M et al. (CC BY 4.0)

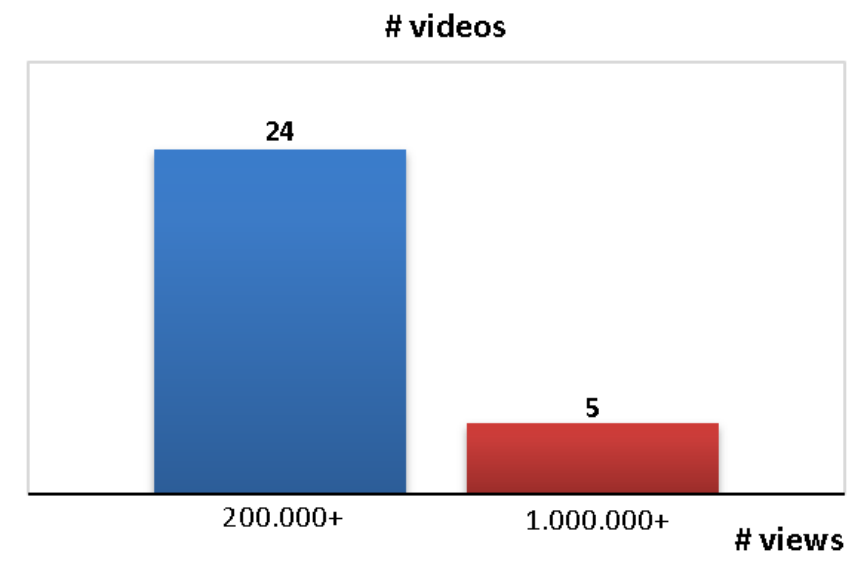

Figure 2. YouTube video search results on August $12^{\text {th }} 2018$ for 'concurso público Brasil' (public tender Brazil).

As mentioned before, the hiring decisions are heavily influenced by the written/oral exam grades of the candidate. Since the CV does not drive the hiring procedures (or only in a very limited amount of cases, see Table 1), candidates with poor CVs (e.g., poor scientific performance) do not have much less chances to be hired as professors as their outperforming counterparts. Studies suggest that public tenders in Brazil assess candidate's research skills in a very superficial way []․ This lack of proven research qualities can be quite a hindrance, since a full-time professor's teaching load is around $20 \mathrm{~h} /$ week (Ziker measured it to be on average $24.5 \mathrm{~h} /$ week [19]); i.e. roughly half of the working load should be assigned to research activities. Authors like Morin [20], Serres [21], and Demo [2] have mentioned for almost half a century that it is good practice that any teacher should be able to identify current research within their teaching. In other words, teaching without research results in courses with obsolete contents [ㅍ].

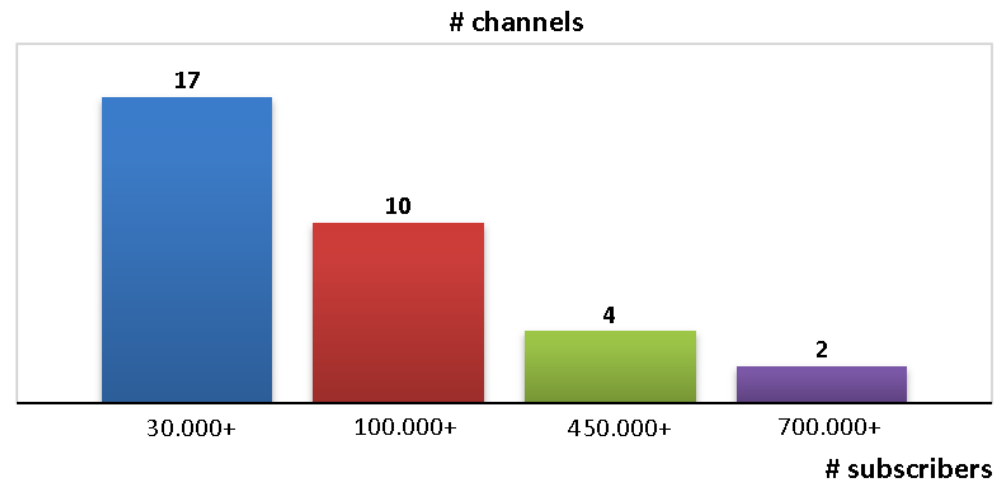

Figure 3. YouTube channel search results on August $12^{\text {th }} 2018$ for 'como passar em concurso público' (how to be approved in a public tender). 
Abambres M, Ribeiro T, Sousa A, Lantsoght E (2018). Ineffective Obsessions in Brazilian Academia and Proposals Towards Meritocracy, hal-02074849

(C) 2018 by Abambres M et al. (CC BY 4.0)

\subsection{Lattes $C V$ features}

Several types of ineffective features found in Lattes CV are described next. 'Missing features' concerns essential information not possible to include or not mandatory when making the curriculum. 'Useless or Unappealing features' are aspects included in the platform that are perceived as such in terms of CV effectiveness for academic job applications. 'Inefficient features' are software issues that make the creation or updating of a Lattes CV a cumbersome task. Lastly, 'Erroneous Portuguese-English translation' contains several examples of how poorly the platform translates to English. Ultimately, a great (yet only) feature of Lattes CV is discussed. These analyses are carried out by evaluating randomly selected curricula on the Lattes platform.

\subsubsection{Missing features}

A key missing feature of any Lattes $\mathrm{CV}$, worth highlighting in first place, is the lack of contact information such as (i) email address, (ii) phone number, or (iii) personal website(s), which is something negatively unique in the world - a CV without direct contact details. The only contacts sometimes provided are the home or institutional postal addresses, which are not relevant nowadays. This feature evidences the inward-oriented nature of Brazilian academia, as it was classified a decade ago [23] .

When registering in the Lattes CV database [24], the 'Areas of expertise' section does not allow the user to select more than one scientific field of expertise, as shown in Figure 4. This improvement would be quite important, both to curriculum quality and to filter researchers when seeking new scientific collaborations. Multidisciplinarity is a requirement from an increasingly complex academic and technical panorama.

When opening existing Lattes CVs online, some have no English version attached, which means it is not mandatory and this feature attests once again the inward-oriented nature of Brazilian academia. The reader

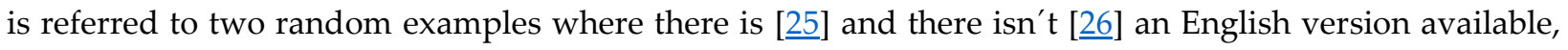
respectively (see upper right corner options on each CV). Furthermore, comparing these two randomly selected profiles, another issue becomes evident: the profile picture is not obligatory. It's not a significant issue, since employer and candidates always meet before hiring, but a curriculum displaying a headshot is a common practice in Latin America that allows attesting authenticity.

Some journal publications on Lattes CV do not exhibit either the Digital Object Identifier (DOI)'s hyperlink, issue number or even the title, thus meaning this information is not mandatory. This lacking information seems unacceptable, since (i) the title is crucial to identify the topic of the paper without leaving the platform, whereas (ii) the DOI's hyperlink allows a direct (either to purchase or to download) online access to the full-text manuscript on the journal's website. An example of this situation was randomly found [27] and is illustrated in Figure 5, where references 6 and 12 do not have any of the aforementioned information - though the metadata is fully available on the journals' websites as shown in Figure 6 and Figure 7 [28,29], respectively. Examples that should be followed are the reborn Microsoft Academic, and Google Scholar, where either (i) references are automatically found and included in one's profile (including a hyperlink to the article's official website), or (ii) a hyperlink is automatically created when a reference is manually added to an author's profile. 
Abambres M, Ribeiro T, Sousa A, Lantsoght E (2018). Ineffective Obsessions in Brazilian Academia and Proposals Towards Meritocracy, hal-02074849

(C) 2018 by Abambres M et al. (CC BY 4.0)

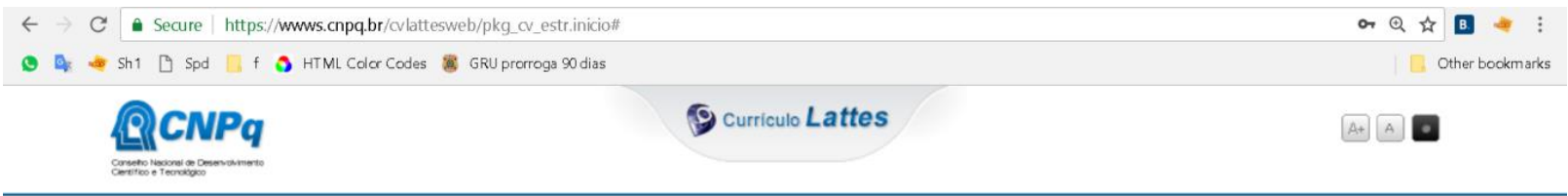

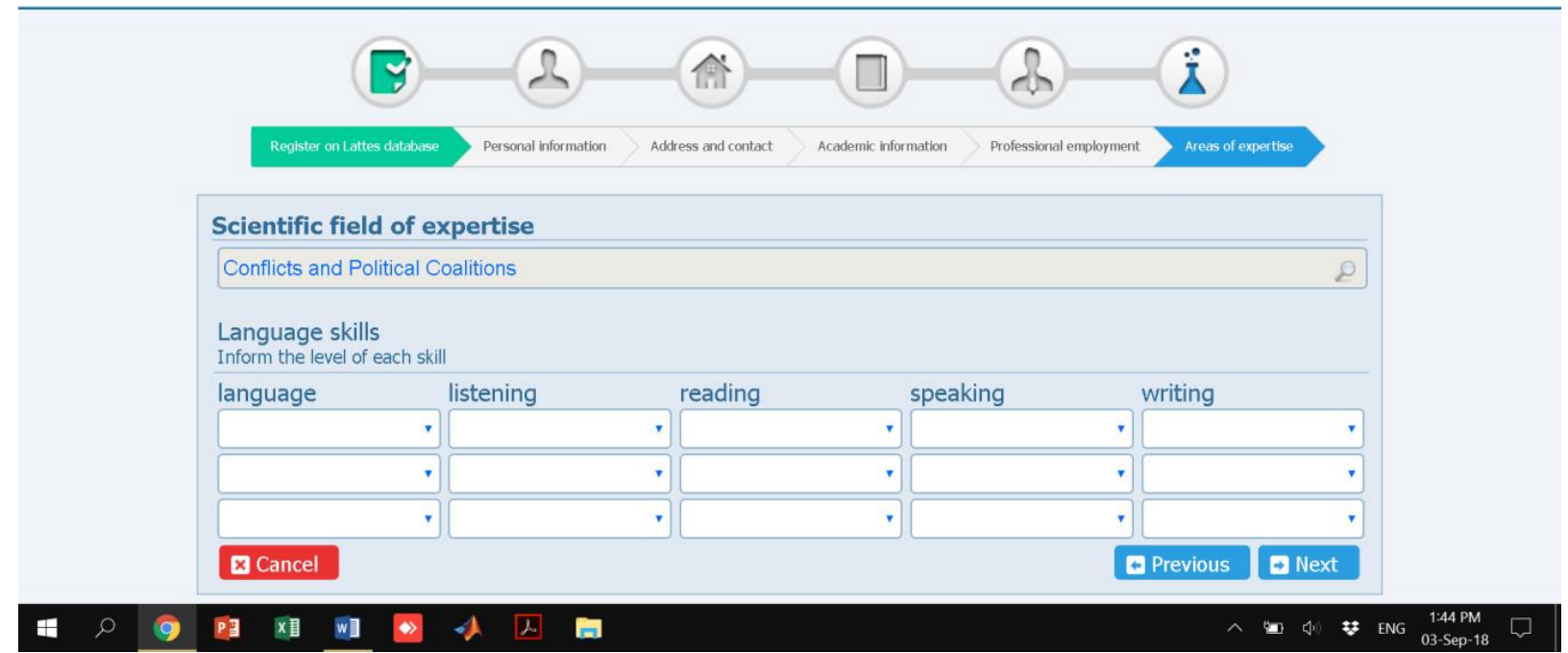

Figure 4. Lattes CV registration [24]: only one field of expertise allowed.

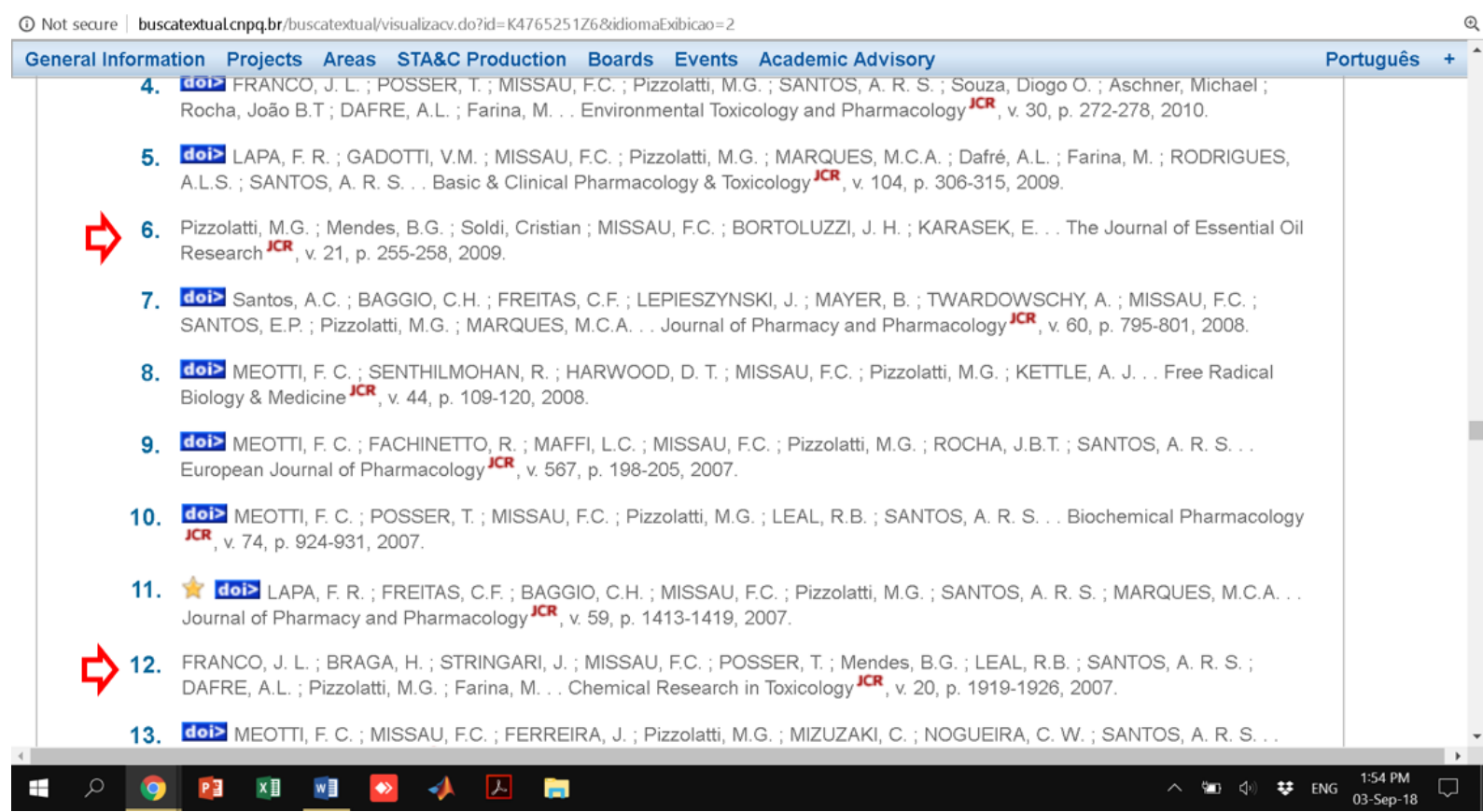


Abambres M, Ribeiro T, Sousa A, Lantsoght E (2018). Ineffective Obsessions in Brazilian Academia and Proposals Towards Meritocracy, hal-02074849

(C) 2018 by Abambres M et al. (CC BY 4.0)

Figure 5. Examples [27] of incomplete references (red arrows before entries numbers 6 and 12) in a Lattes CV.

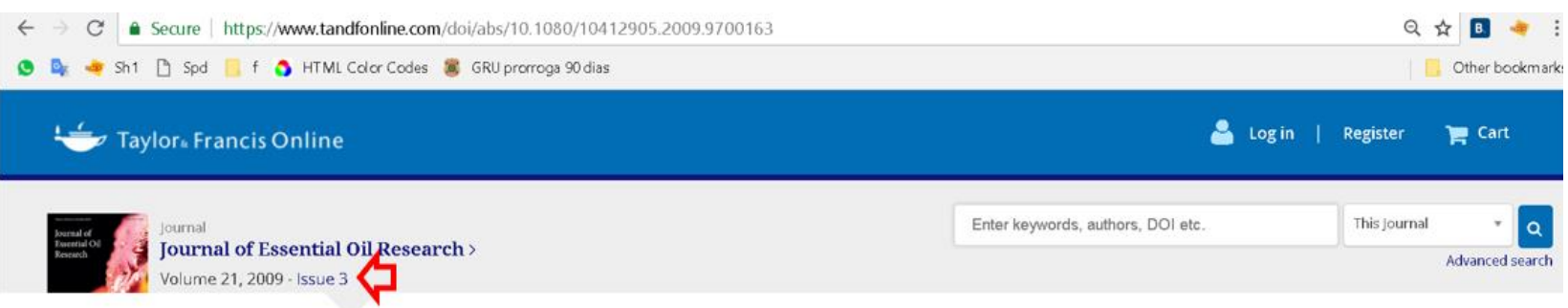

\section{5 \\ 2 \\ crossRef citations \\ 0 \\ Atemetr \\ Analysis of Volatile Compounds Released From Flowers and Roots of Polygala cyparissias and Polygala paniculata by Headspace/SPME}

Moacir G. Pizzolatti, Beatriz G. Mendes, Cristian Soldi, Fabiana C. Missau, Janaina H. Bortoluzzi \& Eduardo Carasek Gs Download citation Q Dhtps://doi.org/10.1080/10412905.2009.9700163

Q References I6 Citations Lill Metrics $\theta$ Reprints \& Permissions

Abstract

G Selecionar idioma $v$

Translator disclaime

Static headspace/SPME volatiles from flowers and roots of the two Polygala species were

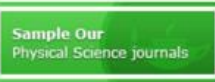

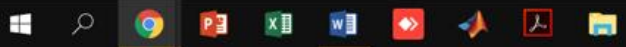

Figure 6. DOI, title, and issue information for paper 6 [28] in Figure 5. 
Abambres M, Ribeiro T, Sousa A, Lantsoght E (2018). Ineffective Obsessions in Brazilian Academia and Proposals Towards Meritocracy, hal-02074849

(C) 2018 by Abambres M et al. (CC BY 4.0)

\begin{tabular}{|l|l|l|l|}
\hline Search & Citation & Subject & Advanced Search \\
\hline Enter search text / DOI & Anywhere & Search \\
\hline Chem. Res. Toxicol. & All Publications/Nebsite & \\
\hline
\end{tabular}

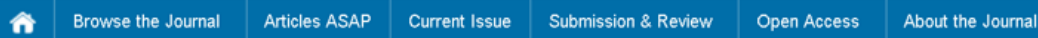

Article

〈 Previous Article Next Article > Table of Contents

Mercurial-Induced Hydrogen Peroxide Generation in Mouse Brain Mitochondria: Protective Effects of Quercetin

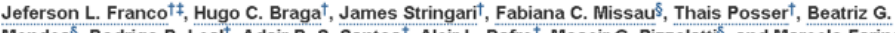
Mendes $^{\S}$, Rodrigo B. Lealt , Adair R. S. Santos ${ }^{\ddagger}$, Alcir L. Dafre ${ }^{\ddagger}$, Moacir G. Pizzolattis Departamento de Bioquimica, Centro de Ciências Biológicas, Departamento de Ciências Fisiológicas, Centro de Ciências Biológicas, and Departamento de Quimica, Centro de Ciências Fisicas e Matemáticas, Universidade Federal de Santa Catarina, 88040-900, Florianópolis, SC, Brazil

Chem. Res. Toxicol., 2007, 20 (12), pp 1919-1926 DOI: $10.1021 / 4 \times 7002323$

Publication Date (Web): October 19, 2007

Copyright $\odot 2007$ American Chemical Society
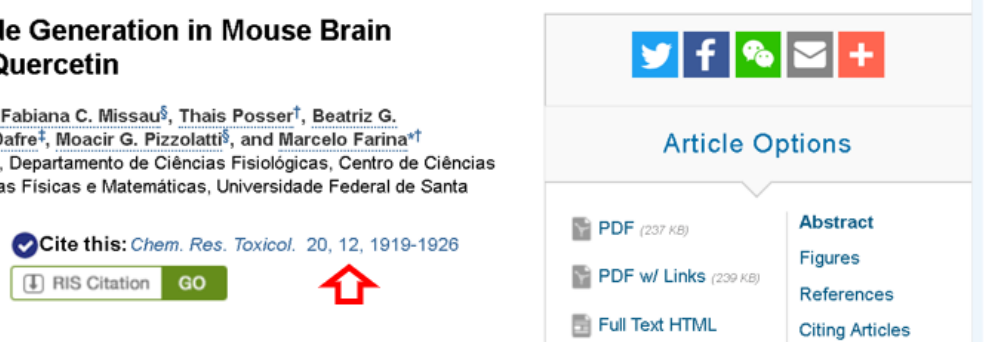

Figure 7. DOI, title, and issue information for paper 12 [29] in Figure 5.

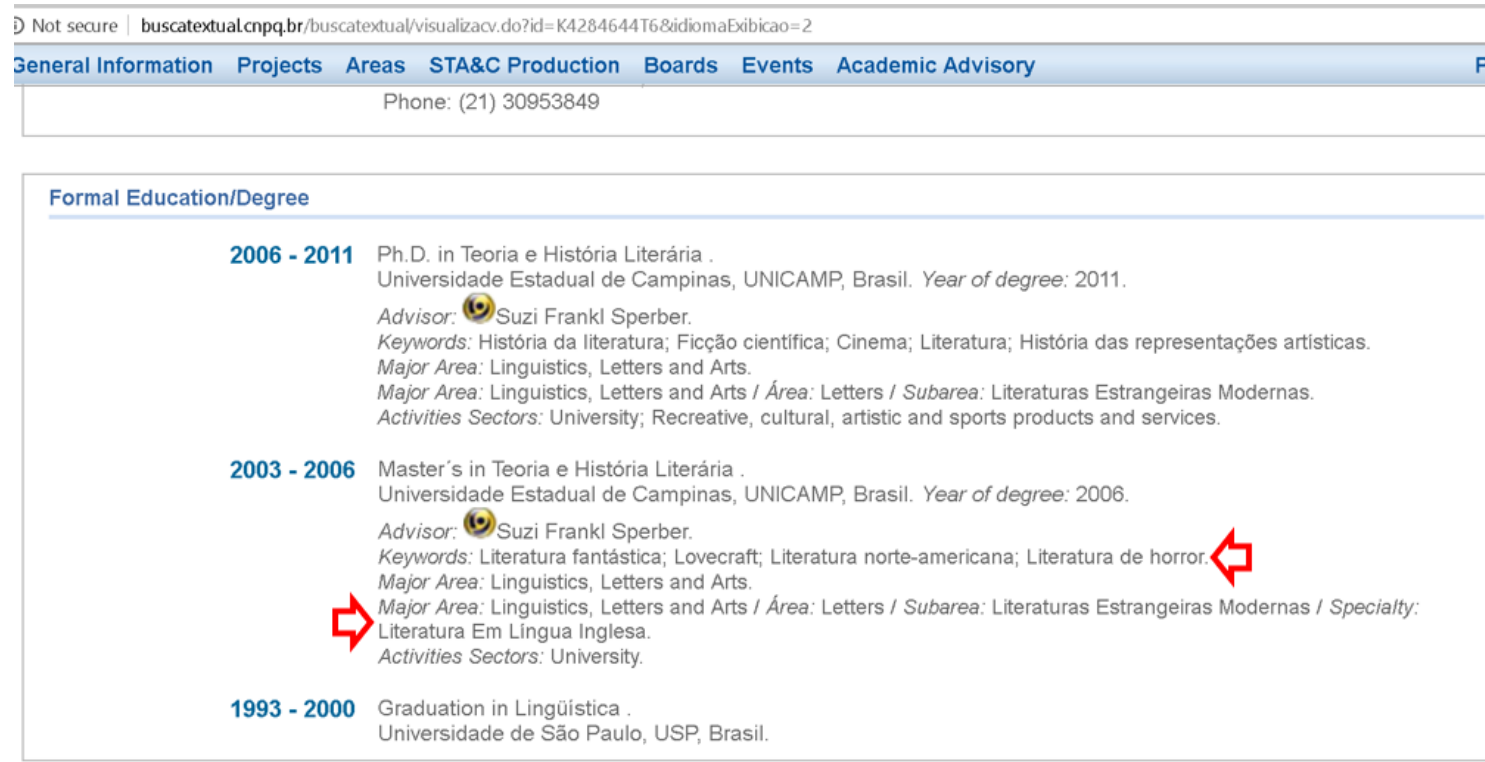

Figure 8. Example [31] of useless features: Major area, Area, Sub-Area, Specialty. 
Abambres M, Ribeiro T, Sousa A, Lantsoght E (2018). Ineffective Obsessions in Brazilian Academia and Proposals Towards Meritocracy, hal-02074849

(C) 2018 by Abambres M et al. (CC BY 4.0)

\subsubsection{Useless or Unappealing features}

Lattes CV does not impose word limits in some sections and fields, which may lead to curricula overloaded with information and unappealing from the recruiters' point of view. A random example can be found in reference [30].

Examples of useless platform features, for instance in the 'Formal education/Degree' section, are fields like (see random example in Figure 8, [31]): (i) Major Area (e.g., 'Linguistics, Letters and Arts'), (ii) Area (e.g., 'Letters'), (iii) Sub-Area (e.g., 'Literaturas Estrangeiras Modernas' - without English translation), and (iv) Specialty (e.g., 'Literatura em Língua Inglesa' - without English translation). Although not mandatory, the inclusion of those fields in the software is not beneficial, since there is a 'keywords' field that serves that purpose.

Lastly, some useless CV sections should be excluded or shortened, such as (e.g. [25]): (i) expanded abstracts and abstracts published in conference proceedings (considering most assessment criteria such abstracts are not relevant; only full conference papers or presentations are valued), (ii) participation in examination boards (since no scientific performance is involved in such decision processes), and (iii) academic advisory (relevant, although the information provided should not exceed the number and type of supervised works - e.g., in a small graph).
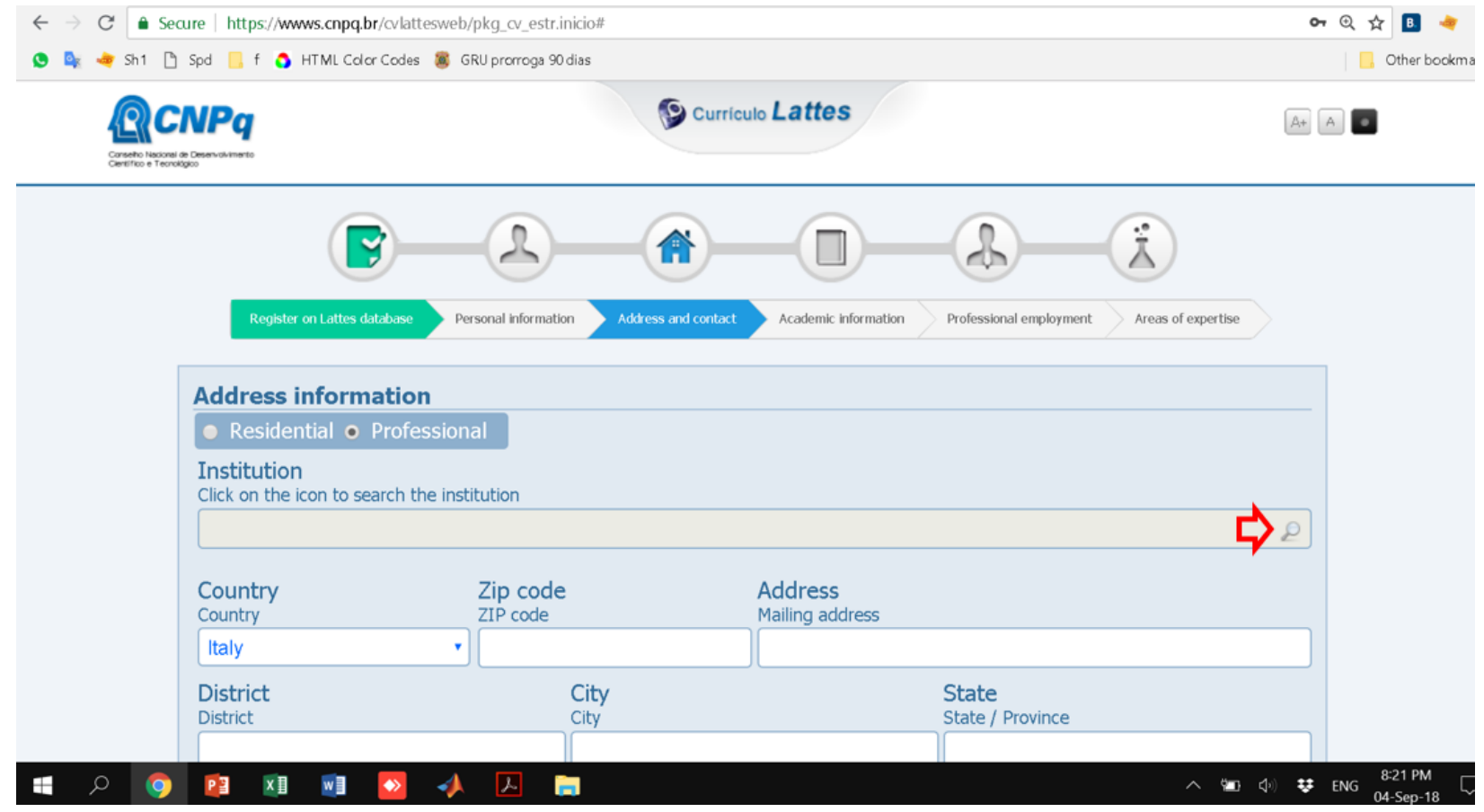

Figure 9. Inefficient feature of Lattes CV's registration platform [24] : selecting the institution (step 1). 
Abambres M, Ribeiro T, Sousa A, Lantsoght E (2018). Ineffective Obsessions in Brazilian Academia and Proposals Towards Meritocracy, hal-02074849

(C) 2018 by Abambres M et al. (CC BY 4.0)

\subsubsection{Inefficient features}

An inefficient characteristic of Lattes CV is related to the 'Address and Contact' section of the registration platform [느] . Like the 'Areas of expertise' section in the same URL, there's no drop-down list with possible choices while typing in the professional institution, as illustrated in Figure 9 and Figure 10. Instead, one must (i) click on the search icon on the right (Figure 9), and then (ii) type in the institution's partial or full name and press 'search' (Figure 10). As shown in Figure 11, all institutions in the database having the entered name are then listed (and only one can be selected). However, if the target institution is not in the database, it can be added by clicking on 'click here' on the bottom-right side in Figure 11. The possibility of registering a new institution with no restrictions makes it quite messy and might lead to people actually belonging to the same institution, being associated to distinct ones in the database. Finally, say that one would pick an institution from the Netherlands (Figure 12), when returning to the previous window (Figure 13) one observes that the institutional country is not automatically set, even though any institution created or selected from the database is always associated to a specific country.

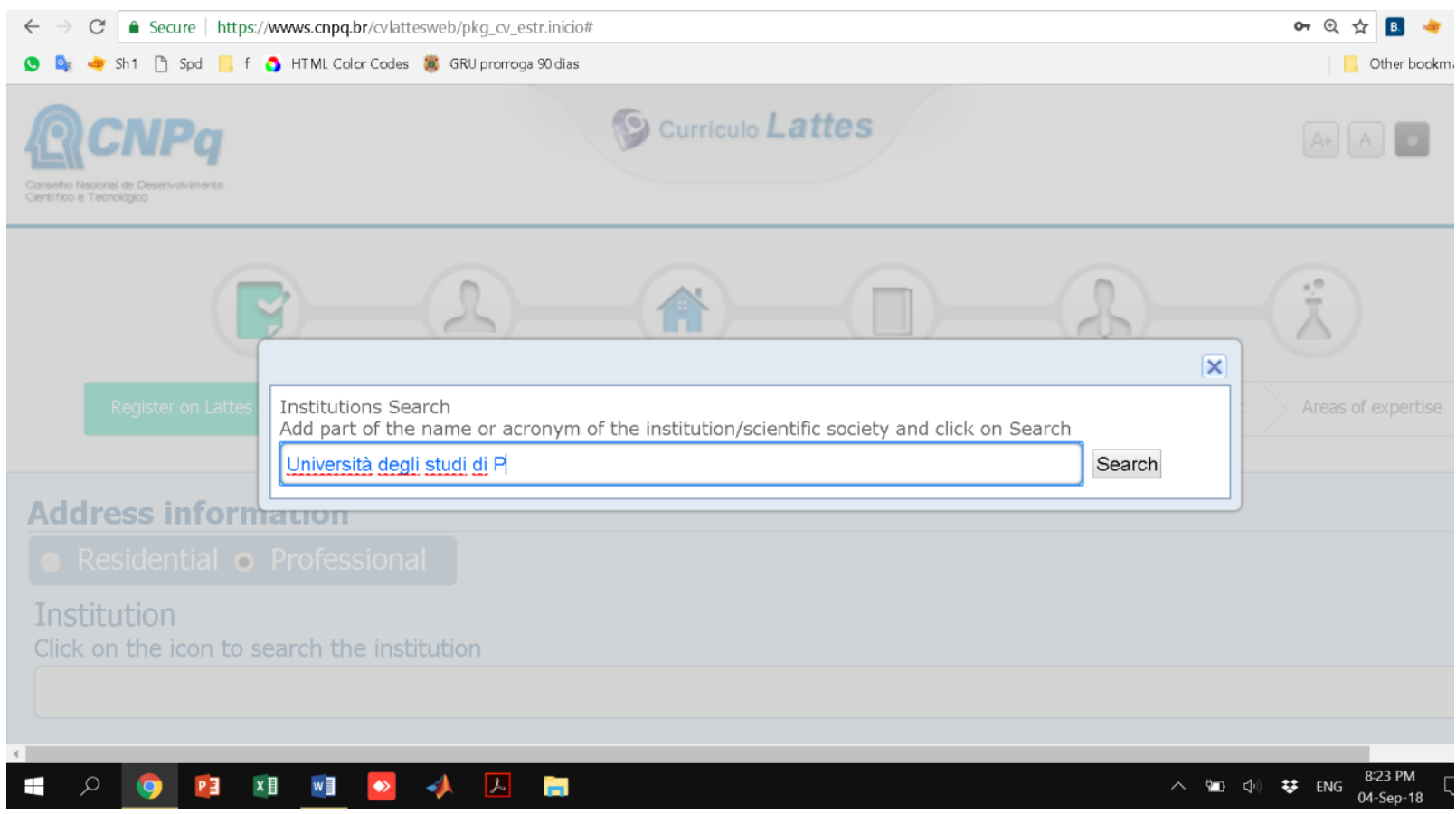

Figure 10. Inefficient feature of Lattes CV's registration platform [24]: selecting the institution (step 2). 
Abambres M, Ribeiro T, Sousa A, Lantsoght E (2018). Ineffective Obsessions in Brazilian Academia and Proposals Towards Meritocracy, hal-02074849

(C) 2018 by Abambres M et al. (CC BY 4.0)

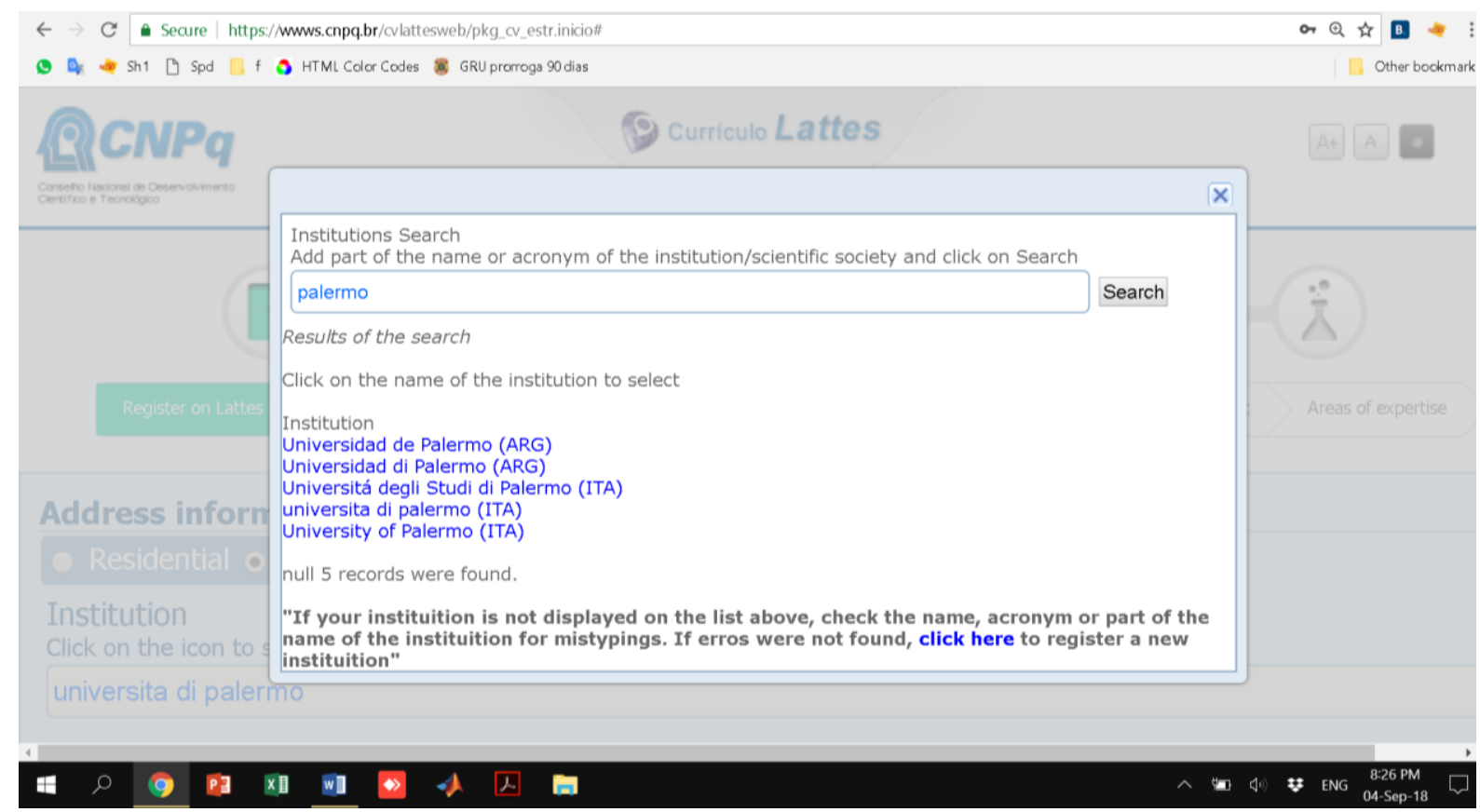

Figure 11. Inefficient feature of Lattes CV's registration platform [24]: selecting the institution (step 3).

\subsubsection{Erroneous Portuguese-English translation}

This section illustrates, through a few examples, how erroneous or unsuitable the Portuguese-English translation of the platform is. Lack of research and technical lexicon is obvious, even though Lattes CV is mostly designed for researchers. Most cases presented herein were found while registering a new CV [24]. Nevertheless, so that the reader understands how general this issue might be, note that 'abstract' in the randomly selected profile referenced in [25] is translated as 'summary'. In Figure 14, 'Structural Mechanics' is referred to as 'Mecanic of the Structures' and 'Metal Structures' as 'Metalic Structures'. In Figure 15, 'Transport Phenomena' is designated as 'Phenomena of Transport', 'Gas Dynamics' as 'Dynamics of the Gases', 'Fluid Mechanics' as 'Mechanic of Fluids', 'Heat Transfer' as 'Transference of Heat', and 'Numerical Methods' as 'Numeric Methods'. 
Abambres M, Ribeiro T, Sousa A, Lantsoght E (2018). Ineffective Obsessions in Brazilian Academia and Proposals Towards Meritocracy, hal-02074849

(C) 2018 by Abambres M et al. (CC BY 4.0)

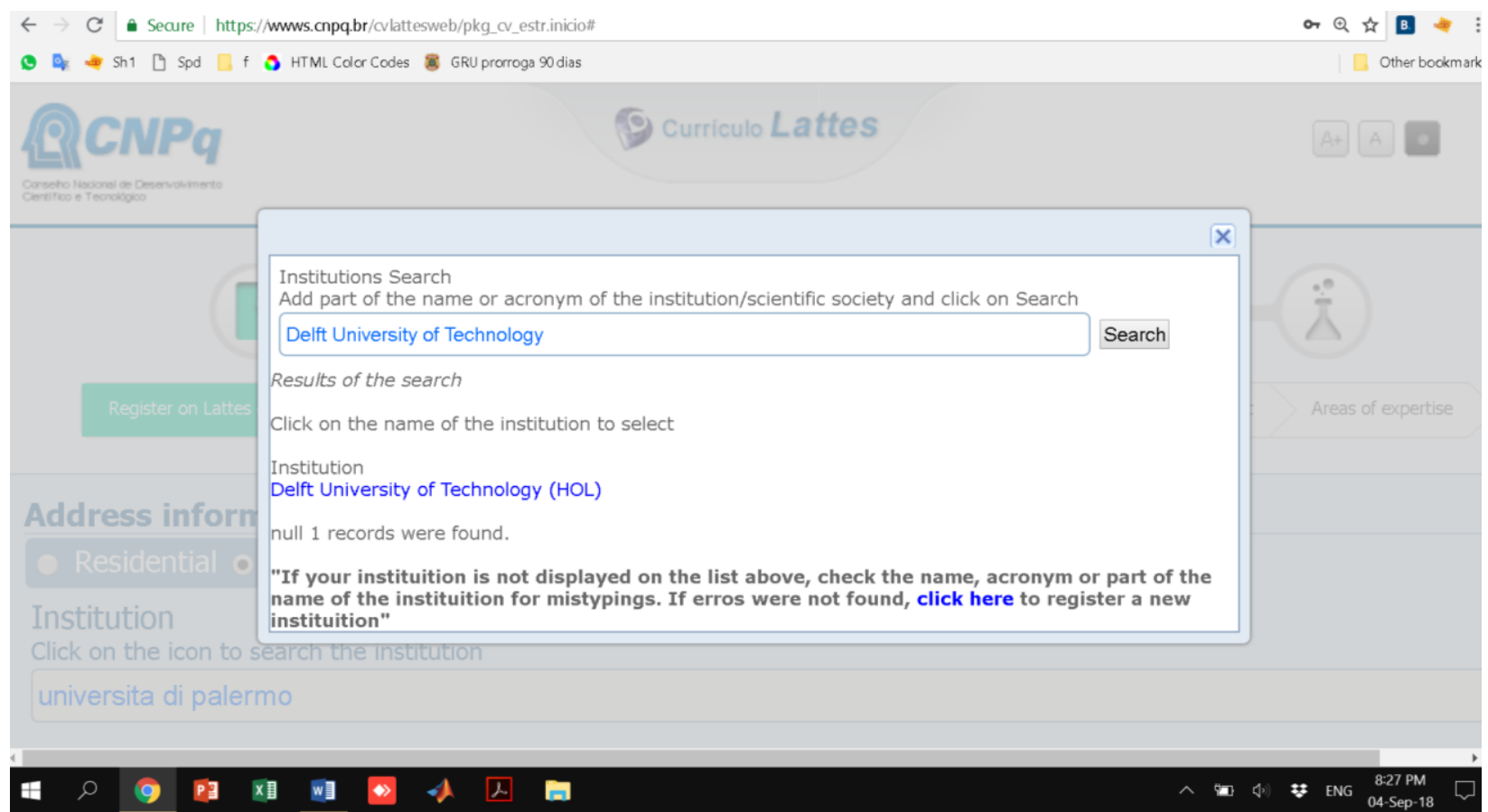

Figure 12. Inefficient feature of Lattes CV's registration platform [24] : selecting an institution from the Netherlands.

\subsubsection{A great (yet only) feature of Lattes CV}

A very important feature in Lattes platform, although inexistent in the English version, as found when comparing the Portuguese and English versions of a randomly selected profile [25], is the indication per journal publication of the number of citations from the Web of Science (WoS), Scopus, and Scielo databases (i.e., given by 'articles indexed' there). 
Abambres M, Ribeiro T, Sousa A, Lantsoght E (2018). Ineffective Obsessions in Brazilian Academia and Proposals Towards Meritocracy, hal-02074849

(C) 2018 by Abambres M et al. (CC BY 4.0)

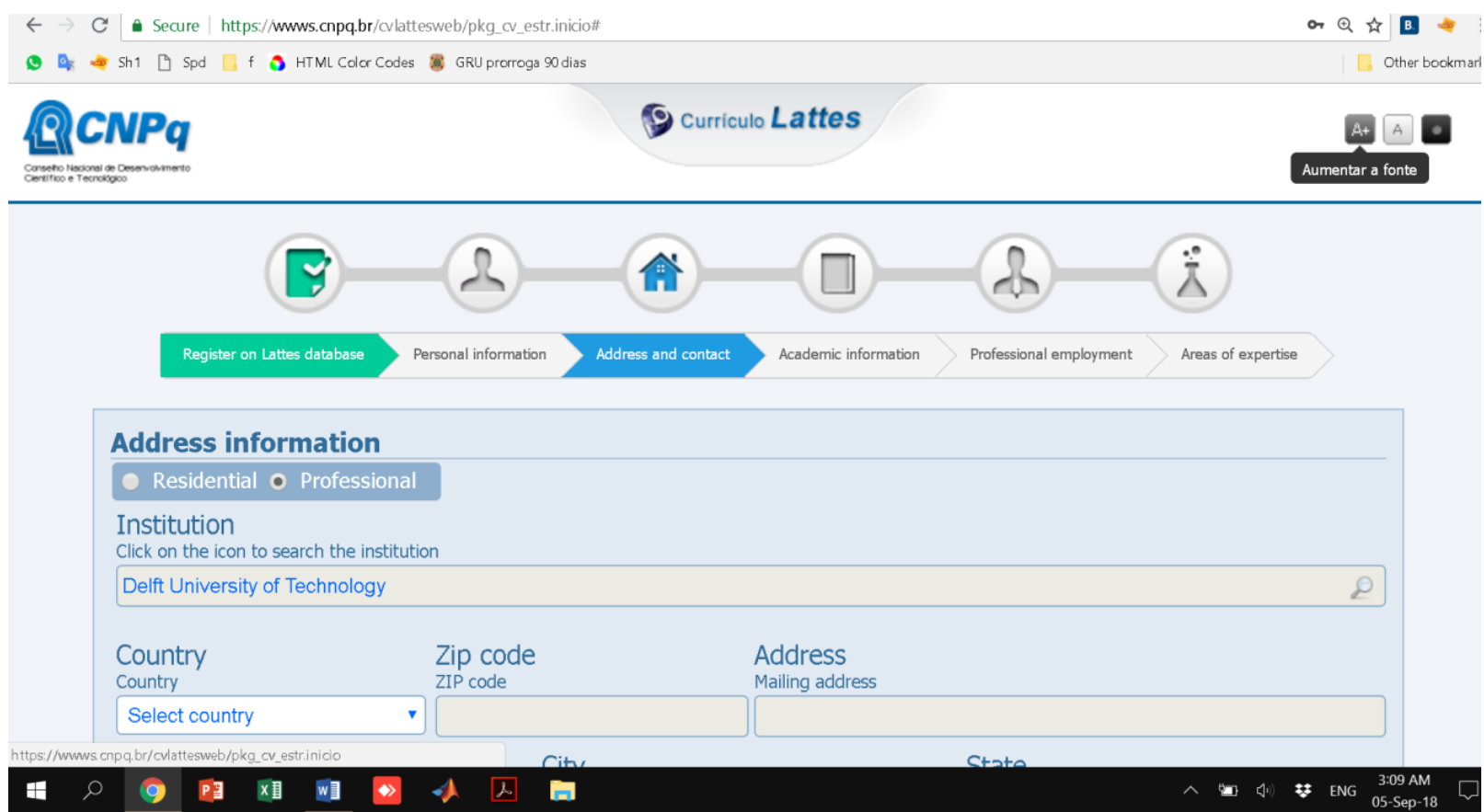

Figure 13. Inefficient feature of Lattes CV's registration platform [녀]: editable country field. 
Abambres M, Ribeiro T, Sousa A, Lantsoght E (2018). Ineffective Obsessions in Brazilian Academia and Proposals Towards Meritocracy, hal-02074849

(C) 2018 by Abambres M et al. (CC BY 4.0)

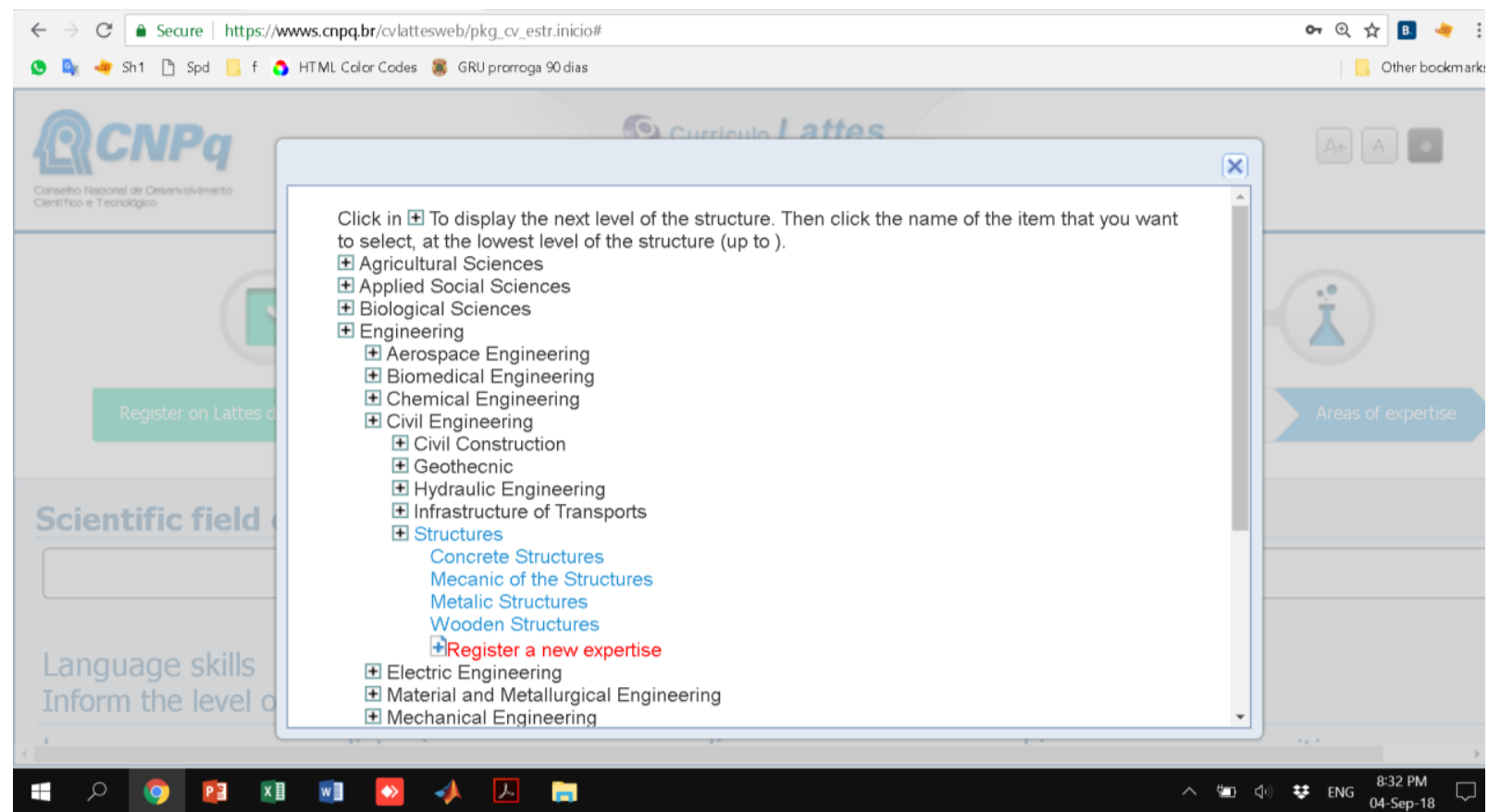

Figure 14. Wrong translations in Lattes CV's section 'Areas of expertise' [24], within 'Structures'.

\section{Suggestions towards meritocracy}

The authors of this manuscript consider the current assessment method of a candidate's knowledge in public tenders highly questionable. The examination suggests disbelief of the candidates' qualifications, experience and skills included in their CVs, all fully proven by institutional certificates, letters of recommendation, and publication metrics. Furthermore, many candidates are graduated from the same institution where they are applying, meaning that even former students' evaluation is not valid to attest their knowledge for the future job. Perhaps the written or oral exams are a way to reduce the considerable number of candidates applying for so few open faculty positions. 
Abambres M, Ribeiro T, Sousa A, Lantsoght E (2018). Ineffective Obsessions in Brazilian Academia and Proposals Towards Meritocracy, hal-02074849

(C) 2018 by Abambres M et al. (CC BY 4.0)

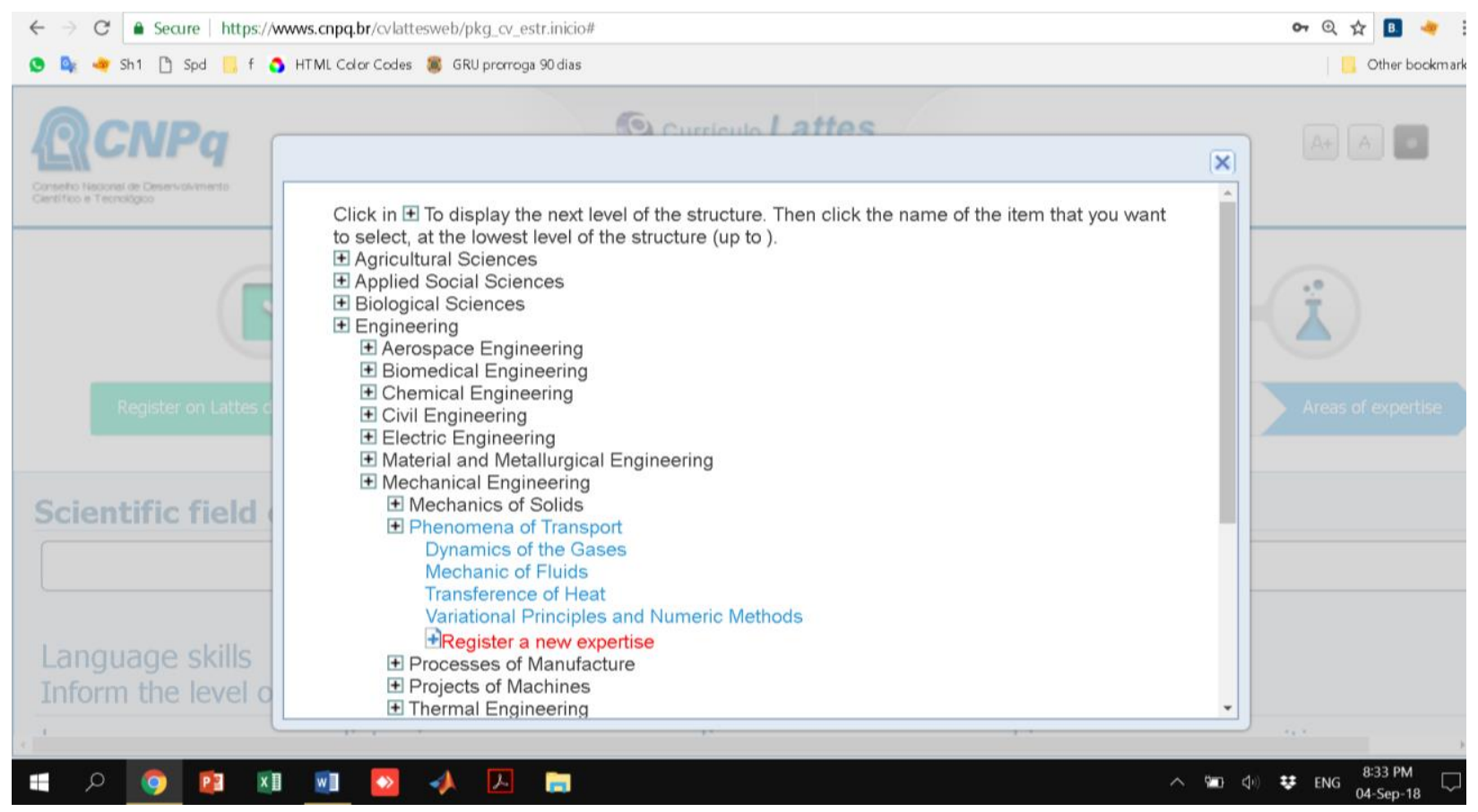

Figure 15. Wrong translations in Lattes CV's section 'Areas of expertise' [24], within 'Phenomena of Transport'.

The authors' proposal for a suitable selection process in any public tender in academia, is the assessment of three elements: (i) full CV, (ii) interview, and (iii) 15 min sample lecture on a given subject (candidate's choice or faculty choice, depending on the teaching goals). Literature on recruiting processes in organizations has highlighted that the interview is one of the most effective instruments used [32], being its adoption in academia recommended by Bohlander et al. [33]. A two-tier process, in which first a preselection of suitable candidates is made based on the $\mathrm{CV}$, and then suitable candidates are invited for the interview and sample lecture, is recommended. For the interview, it is recommended to start with a short presentation of the candidate's previous experience and major achievements, followed by a discussion on his/her teaching and research goals. The interview should be taken by a balanced and diverse (with gender and racial diversity where possible) committee, which includes a student, a junior faculty member, a senior faculty member, and an exterior committee member.

A much easier, rational, and meritocratic way of filtering candidates, promoting equal opportunities, is proposed herein and is fully based on CV evaluation. A weighted formula should still be adopted (see Table 1) to evaluate the $\mathrm{CV}$ of a candidate. The weighted formula should include elements such as (i) grade average in specific graduation courses, (ii) grade average in specific postgraduate courses, (iii) final PhD classification, (iv) scientific performance (e.g., based on citation indexes proposed by Abambres and Arab [ㅍ]), and (v) professional experience. When a position attracts candidates graduated from different 
Abambres M, Ribeiro T, Sousa A, Lantsoght E (2018). Ineffective Obsessions in Brazilian Academia and Proposals Towards Meritocracy, hal-02074849

(C) 2018 by Abambres M et al. (CC BY 4.0)

countries/institutions, comparing grade averages can be mitigated by the local grading practices, unless (i) all grade systems are converted to a single one before averaging (based on institutional reputation), or (ii) other relative metrics are employed. The PhD classification can be used when the candidate graduates with a grade associated with the PhD degree. Moreover, the institution where the candidate graduated from can be evaluated for this classification. The professional experience evaluates the work experience of the candidate only. The teaching skills of the candidate will be evaluated separately in the sample lecture. Other elements that can be evaluated and added to the weighted formula, depending on the position, are: scholarships, prizes and other recognitions, service appointments (e.g., technical committees), and involvement with professional organizations (or their associated student chapters). The weight to be assigned to each of the categories used to evaluate the candidate's CV can be tailored to the academic position he/she is applying for. These procedures are recommended to have a better evaluation of the research performance of a candidate, since the new hire will dedicate roughly $50 \%$ of his/her time to research, as discussed in 3.1. Note that, for a faculty member to dedicate this amount of time to research, it is necessary that administrative tasks be taken by administrative employees. Whereas globally the trend is to reduce support staff and give more administrative tasks to professors, the authors' opinion is that sufficient administrative staff results in a more effective academia.

\section{Discussion}

The analysis in 3.2 describes the shortcomings of Lattes CV platform. In the authors' opinion, Lattes CV should not be imposed as a mandatory CV format in job or funding applications, and most of its features need to be improved to allow its effective use, as described and illustrated in the previously presented analysis. In order to overcome a crucial drawback, the authors recommend the automatic creation and updating of each $\mathrm{CV}$ based on information taken from far more effective, popular and renowned platforms such as Microsoft Academic, Google Scholar, ORCID, or ResearcherID. The authors consider that an effective CV should be as short as possible, and easy to read and compare (the same holds for the platform where the $\mathrm{CV}$ is built).

The feature of showing the number of citations mentioned in 3.2.5 could be introduced into these aforementioned existing platforms (e.g., Microsoft Academic, Google Scholar, Science Open, ResearchGate, ResearcherID), either explicitly, and/or implicitly by providing citation indexes per author based on the proposal of Abambres and Arab [펴], i.e. weighting the authorship order/credit in each publication, as well as the source (WoS, Scopus, or 'others') of each citation. The advantage of this approach is that it provides a combination of different indexing databases, whereas the current Lattes $\mathrm{CV}$ metrics separate the different indexing databases.

For the analysis presented in this paper, the authors requested the permission of CNPq to use screenshots of the Lattes platform and a few stored CVs. Unfortunately, receiving a reply to this request turned out to be rather complicated. Of the 4 contact emails found through the portal, 3 bounced back after writing an email to these accounts on October $15^{\text {th }}$ ( 1 email address) and $17^{\text {th }}$ of 2018 ( 3 addresses found on the website). Moreover, CNPq's Twitter account is not responsive when addressed (contacted on October 
Abambres M, Ribeiro T, Sousa A, Lantsoght E (2018). Ineffective Obsessions in Brazilian Academia and Proposals Towards Meritocracy, hal-02074849

(C) 2018 by Abambres M et al. (CC BY 4.0)

$17^{\text {th }}$ and $18^{\text {th }}$ 2018). Finally, from the single email account that is in operation, the authors were suggested to place the request through the online system e-Ouv. Placing this request (October 19th 2018) has not led to any reply yet. These complex procedures show that the operation of Lattes platform could be improved for queries such as the one described in this paragraph. Given the lack of responsiveness from CNPq, the authors opted not to show the landing pages of the CVs randomly selected for justification purposes, but (i) to provide the links to those profiles in the references, and (ii) to show (and cite) screenshots of the general pages for illustrative purposes. The permission for doing so is tacitly assumed by the lack of responsiveness described.

Based on the investigation carried out and authors' professional experiences, it's no surprise that the Brazilian academic market is still found to be inward-oriented, despite the stronger links with foreign academia. A limited number of foreign students and professionals (especially from outside Latin America) [14] are found in Brazilian academia, and Brazilian scientists still [35] publish a significant amount of work in national journals, which sometimes are only available in Portuguese. By limiting its capacity of attracting foreign talent, Brazilian academia fails not only to take advantage of the best possible candidates, either national or international, but also to promote diversity and pluralism.

\section{Conclusions}

This paper described two major ineffective Brazilian obsessions in academia - the pseudo-meritocratic public tender, and the Lattes CV. Alternatives to replace or improve these two paradigms were proposed, being the most important:

(i) Assessment of public tender attendees for faculty positions based on CV, interview, and short sample lecture.

(ii) Waive Lattes CV as mandatory in job or funding applications, and use a regular CV instead.

(iii) Allow Lattes CV to automatically be created or updated based on information taken from far more effective, popular, and renowned platforms such as Microsoft Academic, Google Scholar, ORCID or ResearcherID.

Although the lack of research funding in Brazil is clearly the hot topic in the social and news media, this is clearly not the only solution its academia needs to globally thrive. The authors hope to have given a relevant contribution for Brazil to prosper academically and scientifically in the near future.

Author Contributions: Conceptualization and first-draft writing: MA; Validation: EL; All other contributions: equally distributed among all authors (AS's contribution was given before April 1 ${ }^{\text {st }}, 2018$ ).

Conflicts of Interest: The authors declare no conflict of interest. 
Abambres M, Ribeiro T, Sousa A, Lantsoght E (2018). Ineffective Obsessions in Brazilian Academia and Proposals Towards Meritocracy, hal-02074849

(C) 2018 by Abambres M et al. (CC BY 4.0)

\section{References}

1. Barbosa, L. Meritocracia à brasileira: o que é desempenho no Brasil? (in Portuguese). Revista do Serviço Público (Ano 47) 1996, 120, 58-102.

2. Pinheiro, J. Brazil Is a Flawed Meritocracy in More Ways than Just One. Availabe online: https://www1.folha.uol.com.br/internacional/en/brazil/2018/05/1967769-brazil-is-a-flawed-meritocracy-in-moreways-than-just-one.shtml; Archived at http://archive.fo/jJ992 (accessed on August 5th, 2018).

3. Fan, J. A Brazilian Thriller That Exposes the Sinister Side of Meritocracy. Availabe online: https://www.newyorker.com/culture/cultural-comment/a-brazilian-thriller-that-exposes-the-sinister-side-ofmeritocracy (accessed on August 5th 2018).

4. de Araújo, H.N.T. A Construção do Ethos Concurseiro: Mérito e Experiência Moral na Competição por Cargos Públicos. Federal University of Paraiba, João Pessoa, Brazil, 2016.

5. Siqueira, E.S.; Binotto, E.; Silva, F.M.V.d.; Hoff, D.N. Seleção de Docentes em Universidades Federais: uma análise dos regulamentos. Ensaio: Avaliação e Políticas Públicas em Educação 2012, 20, 725-748.

6. Mena-Chalco, J.P.; Cesar Junior, R.M. ScriptLattes: an open-source knowledge extraction system from the Lattes platform. Journal of the Brazilian Computer Society 2009, 15, 31-39.

7. Fundação Universidade de Brasília (FUB/UnB). Edital de Abertura de Concurso Público Docente N. 17 de 22/01/2018 (in Portuguese); Brasília, Brasil, 2018.

8. Governo do Estado de São Paulo (GESP). Diário Oficial (in Portuguese). 2018, 128, 233.

9. Imprensa Nacional. Diário Oficial da União (in Portuguese). 2018, 87, 1-274.

10. Bertonha, J. Produção e produtividade no meio acadêmico: A “ditadura do Lattes” e a Universidade contemporânea (in Portuguese). Revista Espaço Acadêmico 2009, 100, 6-9.

11. Dias, T.M.R.; Moita, G.F.; Dias, P.M. Adoção da plataforma lattes como fonte de dados para caracterização de redes científicas. 2016 2016, 21, 11, doi:10.5007/1518-2924.2016v21n47p16.

12. Fontainha, F.C. Meritocracia e Concursos Públicos (in Portuguese). Insight Inteligência 2013, XVI, 52-66.

13. Fontainha, F.C.; Geraldo, P.H.B.; Veronese, A.; Alves, C.S.; Figueiredo, B.H.; Waldburger, J. Processos Seletivos para a Contratação de Servidores Públicos: Brasil, O País Dos Concursos? (in Portuguese). ; Fundação Getulio Vargas (FGV Direito Rio): Rio De Janeiro, Brazil, 2014.

14. Downie, A. Brazilian Universities Find Challenges in Internationalization. Availabe online: https://www.chronicle.com/article/Brazilian-Universities-Find/124312; Archived at http://archive.fo/Pmu2i (accessed on October 19th 2018)

15. Douglas, W. Como passar em provas e concursos (in Portuguese), 29th Edition; Impetus: Rio de Janeiro, Brazil, 2015.

16. Meirelles, A. Como estudar para concursos (in Portuguese), 4th edition; Juspodivm: Salvador, Brazil, 2017.

17. Viegas, A. Manual de um concurseiro: o caminho das pessoas comuns (in Portuguese), 6th edition; Método: São Paulo, Brazil, 2010.

18. vBulletin Solutions, I. Fórum Concurseiros. Availabe online: http://www.forumconcurseiros.com/forum/forum; Archived at https://archive.fo/mgrG8 (accessed on September 3rd, 2018).

19. Ziker, J. The Long, Lonely Job of Homo academicus - Focusing the research lens on the professor's own schedule. Availabe online: https://thebluereview.org/faculty-time-allocation/; Archived at http://archive.fo/qOvCq (accessed on October 19th 2018). 
Abambres M, Ribeiro T, Sousa A, Lantsoght E (2018). Ineffective Obsessions in Brazilian Academia and Proposals Towards Meritocracy, hal-02074849

(C) 2018 by Abambres M et al. (CC BY 4.0)

20. Morin, E. Introdução ao pensamento complexo (in Portuguese); Instituto Piaget: Lisboa, Portugal, 1990.

21. Serres, M. Filosofia mestiça: Le tiers instruit; Nova Fronteira: Rio de Janeiro, Brazil, 1993.

22. Demo, P. Avaliação sob o olhar propedêutico; Papirus: São Paulo, Brazil, 1996.

23. Balbachevsky, E.; Schwartzman, S.; Alves, N.N.; do Santos, D.F.F.; Duarte, T.S.B. Brazilian Academic Profession: some recent trends. In Proceedings of The Changing Academic Profession in the International Comparative and Quantitative Perspectives, Hiroshima, Japan.

24. Conselho Nacional de Desenvolvimento Científico e Tecnológico (CNPq). Plataforma Lattes - Cadastrar novo currículo. Availabe online: archived at https://archive.fo/9ZHGY (accessed on September 3rd 2018).

25. Barham, E. Elizabeth Joan Barham's Lattes CV. Availabe online: https://archive.is/37K6s (English) and https://archive.fo/A0bEt (Portuguese) - archived versions (accessed on September 4th 2018).

26. Marchesi, I.M. Isadora Moraes Marchesi's Lattes CV. Availabe online: archived at https://archive.fo/189pB (accessed on September 3rd 2018).

27. Missau, F.C. Fabiana Cristina Missau's Lattes CV. Availabe online: archived at https://archive.fo/ILM4p (accessed on September 3rd 2018).

28. Pizzolatti, M.G.; Mendes, B.G.; Soldi, C.; Missau, F.C.; Bortoluzzi, J.H.; Carasek, E. Analysis of Volatile Compounds Released From Flowers and Roots of Polygala cyparissias and Polygala paniculata by Headspace/SPME. Journal of Essential Oil Research 2009, 21, 255-258, doi:10.1080/10412905.2009.9700163.

29. Franco, J.L.; Braga, H.C.; Stringari, J.; Missau, F.C.; Posser, T.; Mendes, B.G.; Leal, R.B.; Santos, A.R.S.; Dafre, A.L.; Pizzolatti, M.G., et al. Mercurial-Induced Hydrogen Peroxide Generation in Mouse Brain Mitochondria: Protective Effects of Quercetin. Chemical Research in Toxicology 2007, 20, 1919-1926, doi:10.1021/tx7002323.

30. Kiill, C.P. Charlene Priscila Kiill's Lattes CV. Availabe online: archived at https://archive.fo/6VfA5 (accessed on September 4 th 2018).

31. Miguel, A.D. Alcebiades Diniz Miguel's Lattes CV. Availabe online: archived at https://archive.fo/h5NEm (accessed on September 4th 2018).

32. Limongi-França, A.C. Práticas de recursos humanos - PRH; Atlas: São Paulo, Brazil, 2007.

33. Bohlander, G.; Snell, S.; Sherman, A. Administração de recursos humanos; Pioneira Thomson Learning: São Paulo, Brazil, 2003.

34. Abambres, M.; Arab, P. Citation Indexes Accounting for Authorship Order in Coauthored Research - Review and New Proposal. Science \& Technology Libraries 2016, 35, 263-278, doi:10.1080/0194262X.2016.1242450.

35. Glänzel, W.; Leta, J.; Thijs, B. Science in Brazil. Part 1: A macro-level comparative study. Scientometrics 2006, 67, 67-86, doi:10.1007/s11192-006-0055-7.

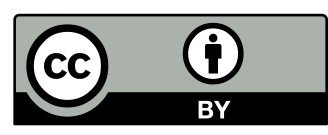

(C) 2018 by Abambres et al. Open access publication under the terms and conditions of the Creative Commons Attribution 4.0 (CC BY 4.0) license

(http://creativecommons.org/licenses/by/4.0/). 